\title{
Cytology and Histology of the Cerebral Neurosecretory Systems in some Tropical Earthworm Species

\author{
Chaudhuri PS* and Dipanwita Banik
}

Department of Zoology, Earthworm Research Laboratory, Tripura University, Suryamaninagar-799022, Tripura, India

\begin{abstract}
The cerebral ganglia of tropical earthworms, Metaphire houlleti, Metaphire posthuma (Megascolecidae), Eutyphoeus gammiei (Octochaetidae) and Eudrilus eugeniae (Eudrilidae) revealed mainly two categories of neurosecretory cells (NSCs) - A cells and B cells. Thick cortical tier of A cells stained intensely with AF and were differentiated into $A 1, A 2$ and $A 3$ types on the basis of their shape, size and location. The sub-cortical $B$ cells, lying close to the neuropile stained lightly with AF. While the axons of A1 cells discharged neurosecretory material (NSM) beneath the perineurium, those of $A 2, A 3$ and $B$ cells generally transported NSM at the margin of the neuropile forming "accumulation zone". Our present study revealed that in earthworms, in absence of any well-defined neurohaemal organ, there was a phenomenal deposition of NSM in the "accumulation zone" or tissue spaces beneath the highly vascular perineurium from where the secretion readily entered the capillaries by diffusion to meet the physiological demand of the animal.
\end{abstract}

Keywords: Neurosecretory cells; Cerebral ganglia; Accumulation zone; Neuropile; Metaphire houlleti; Metaphire posthuma; Eutyphoeus gammiei; Eudrilus eugeniae

\section{Introduction}

Neurosecretory cells (NSCs) with endocrine functions have been described in majority of triploblastic animals. Since the initial description of these cells in Lumbricus terrestris [1] there have been numerous studies on the structure, types and role of these cells in the central nervous system (CNS) of oligochaetes [2-4]. According to Scharrer and Scharrer [5], almost one half of the cerebral ganglia in oligochaetes is glandular. In fact NSCs within the CNS of earthworms are regarded as the source of "vascular" hormones controlling many biological activities such as growth, osmoregulation [6], reproduction [7-9 ], thermal acclimation [10], food intake [11], regeneration [12,13] and light reaction [14]. In absence of any definite neurohaemal organ, as found in polychaetes and arthropods $[15,16]$, the neurosecretory system in oligochaetes deserve special attention because of being the first class of coelomates with closed vascular system.

Due to difference in nomenclature of NSC types, variations in their morphology and the modes of release of hormones in absence of a welldeveloped storage release organ [2], we have studied the neurosecretory systems in the cerebral ganglia of some tropical earthworms belonging to different ecological categories [17] viz.; surface living phytophagous epigeic (Eudrilus eugeniae, Family: Eudrilidae ), geophagous horizontal burrower endogeic (Metaphire posthuma, Family: Megascolecidae), geophagous vertical burrower endoanecic (Eutyphoeus gammiei, Family: Octochaetidae) and phytogeophagous vertical burrower anecic earthworm (Metaphire houlleti, Family: Megascolecidae).

In our present light microscopic study we have addressed to the following questions: 1) What are the neurosecretory cell types in the cerebral ganglia of these tropical species of earthworms? 2) Being the first class of coelomates do they possess any specific storage-release site for neurosecretory material (NSM)? 3) Is there formation of any neurosecretory cell group and axon bundle as found in insects, crustaceans and chellicerate arthropods and lastly 4) Do the pattern of the cerebral neurosecretory system differs among the earthworm species of different ecological categories?

\section{Materials and Methods}

Mature earthworms, Metaphire houlleti (length 150-200 mm, diameter 5-7 mm), M. posthuma (L 100-150 mm, D 5-8 mm), Eutyphoeus gammiei (L 250-400 mm, D 7-10 mm) were collected from neighbouring areas of Agartala, Tripura and acclimated in laboratory conditions $\left(27-30^{\circ} \mathrm{C}\right.$, moisture $\left.85 \%\right)$ for 2 weeks. Vermicomposting earthworm, Eudrilus eugeniae (L 100-150 mm, D 5-7mm) were obtained from laboratory stock culture. After anesthetization [18], cerebral ganglia (located in the third segment) of at least 20 individuals of each species were quickly dissected out and fixed in $2 \%$ Ca-Bouin's fluid for 18 hours. Tissues were dehydrated in alcohol, cleared in xylol and embedded in paraffin $\left(58-60^{\circ} \mathrm{C}\right)$. Serial frontal section of $7 \mu \mathrm{m}$ thickness were stained with Gomori's Chrome alum haematoxylene phloxin (CAHP) as modified by Bargmann [19] and simplified Aldehyde Fuchsin [20] staining technique. Photographs were taken by broad-field light microscope (Leica DM1000).

\section{Results}

In the bilobed cerebral ganglia of earthworms, NSCs formed several layered thick tier beneath the perineurium above which was the noncellular neural lamella (Figure 1). Number of NSCs gradually declined from the dorsal to the ventral part of cerebral ganglia. Dorsally, the lateral part of the cerebral ganglion showed thick and compact arrangement of numerous NSCs in contrast to its mid part (Figure 1a). Beneath the cortical tier of NSCs was the fibrous and vascularised neuropile (Figures 1a and 1b). Distribution of NSM at the margin of neuropile, as well as in the neighbourhood of intra and extra ganglionic blood capillaries

*Corresponding author: Chaudhuri PS, Department of Zoology, Earthworm Research Laboratory, Tripura University, Suryamaninagar-799022, Tripura, India, Tel: 0381237 4802; E-mail: priya_1956@rediffmail.com

Received July 16, 2015; Accepted August 12, 2015; Published August 15, 2015.

Citation: Chaudhuri PS, Banik D (2015) Cytology and Histology of the Cerebral Neurosecretory Systems in some Tropical Earthworm Species. J Cytol Histol 6 : 367j. doi:10.4172/2157-7099.1000367

Copyright: @ 2015 Chaudhuri PS, et al. This is an open-access article distributed under the terms of the Creative Commons Attribution License, which permits unrestricted use, distribution, and reproduction in any medium, provided the original author and source are credited. 


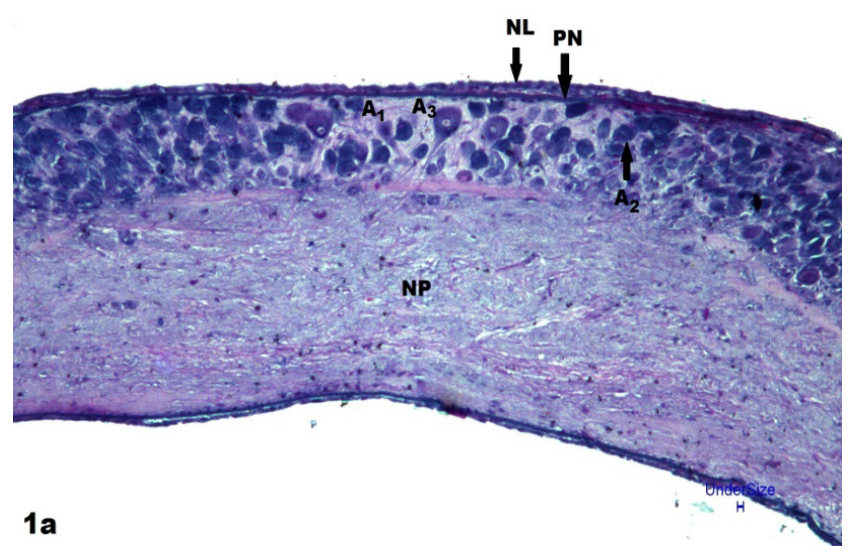

Figure 1a: Frontal section showing disposition of CAHP-positive A1, A2 and A3 NSCs in the postero-median and the postero-dorsal part of the cerebral ganglion of Metaphire houlleti. Note compact arrangement of NSCs in the dorso- lateral part of the cerebral ganglia compared to its median part.100X

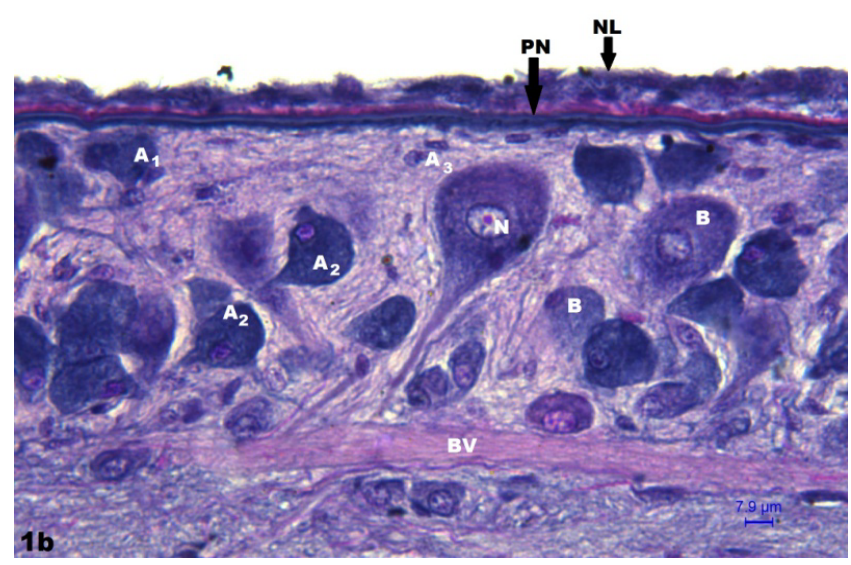

Figure 1b: Frontal section showing distribution of CAHP positive $A 1$, A2, A3 and B NSCs in the dorso- median part of cerebral ganglion of $M$. houlleti. Note axonal transport of NSM from A3 cell to neuropile traversing a blood vessel. $400 \mathrm{X}$

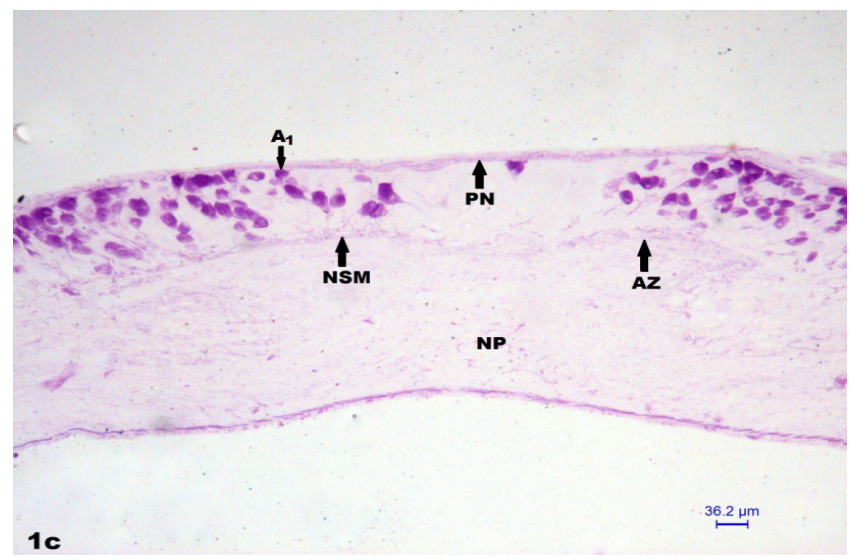

Figure 1c: Frontal section showing thick cortical tier of different types of AF positive cerebral NSCs and 'accumulation zone' of NSM at the margin of the neuropile in $M$. houlleti. Note distribution of A1- cells beneath the perineurium.100X.

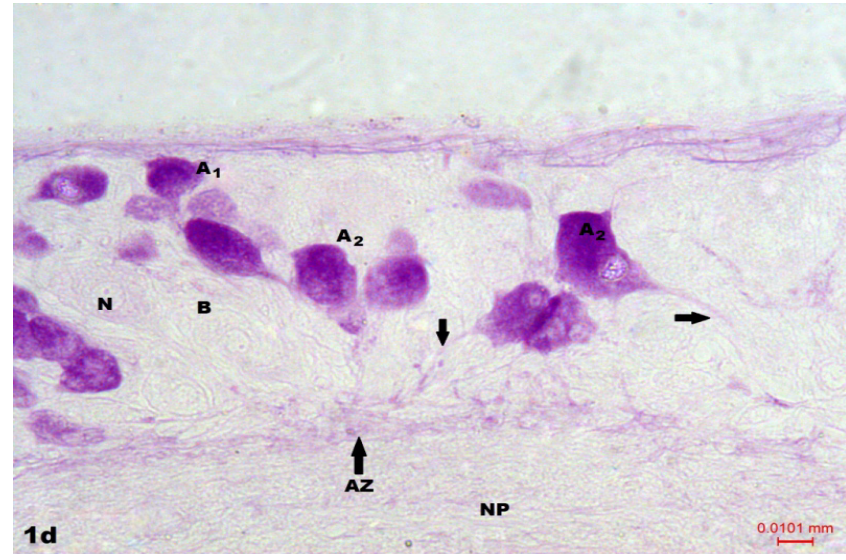

Figure 1d: Frontal section of the cerebral ganglion in $M$. houlleti showing secretory cycle in AF positive A2 cells with axon charged with in the NSM. Note rich distribution of NSM at the margin of neuropile (NP) accumulation zone (AZ) and one multipolar A1 cell beneath the perineurium .400X.

was not seldom (Figures 1b-1d). In contrast to the cerebral NSCs in $M$. posthuma, M. houlleti and E. gammiei, those in E. eugeniae had more compact arrangement of NSCs having smaller dimensions (Figure 1a). Besides the difference in neurosecretory cell sizes in the cerebral ganglia of the earthworm species under different ecological categories, the general pattern of cerebral neurosecretory system followed a similar pattern. In our present paper basic works in distinguishing NSC types were based on $M$. houllet $i$ and then a comparative survey was made for the other three species (Tables 1 and 2).

Primarily on the basis of staining intensity two major categories of NSCs were observed in the postero-dorsal part of the cerebral ganglia in the four earthworm species. These were deeply stained $\mathbf{A}$ cells and light or moderately stained B cells. All the cells irrespective of their types were CAHP positive but only A cells particularly the $\mathbf{A 1}$ and A2 cells stained very deeply with AF stains (Figures 1a and 1b). Small neuroglial cells, undifferentiated nerve cells and ordinary neurons were also present in the cortical cell tier.

Shape, size, distribution and staining characteristics of cerebral NSC types are given in Tables 1 and 2.

A-Cells: A- cells were the predominating NSCs distributed beneath the perineurium as a thick cortical tier of 5-10 layers at the postero- dorsal part of the brain (Figures 1a-1d and 2). They often showed distinct secretory cycles with different phases of secretion and cytoplasmic vacuoles (Figure $2 b$ ). Their number was maximum at the postero-lateral, moderate at the postero-median and minimum at the anterior and ventral part of the cerebral ganglia (Figure 1c). These cells were oval and pear shaped with eccentric oval or spherical nuclei. Cytoplasm was charged with deeply AF- stained colloidal secretory materials that appeared in the form of beads in the axon that often took moliniform appearance as found in E. gammiei (Figures 3 and $4 \mathrm{~b}$ ). In contrast to summer condition, the numbers of A-cells with the amount of neurosecretory material (NSM) in each cell were far greater in the earthworms collected during winter. On the basis of shape, size and distribution A-cells were further categorized into following sub-types:

i)A1-Cells: Smallest unipolar or multipolar A1-NSCs with variable shapes, homogeneously deep stained cytoplasm and ill-defined nuclei formed superficial single or double cell layers just beneath the perineurium (Figures 1a-1d). Generally axons of these cells were very 
Citation: Chaudhuri PS, Banik D (2015) Cytology and Histology of the Cerebral Neurosecretory Systems in some Tropical Earthworm Species. J Cytol Histol 6: 367j. doi:10.4172/2157-7099.1000367

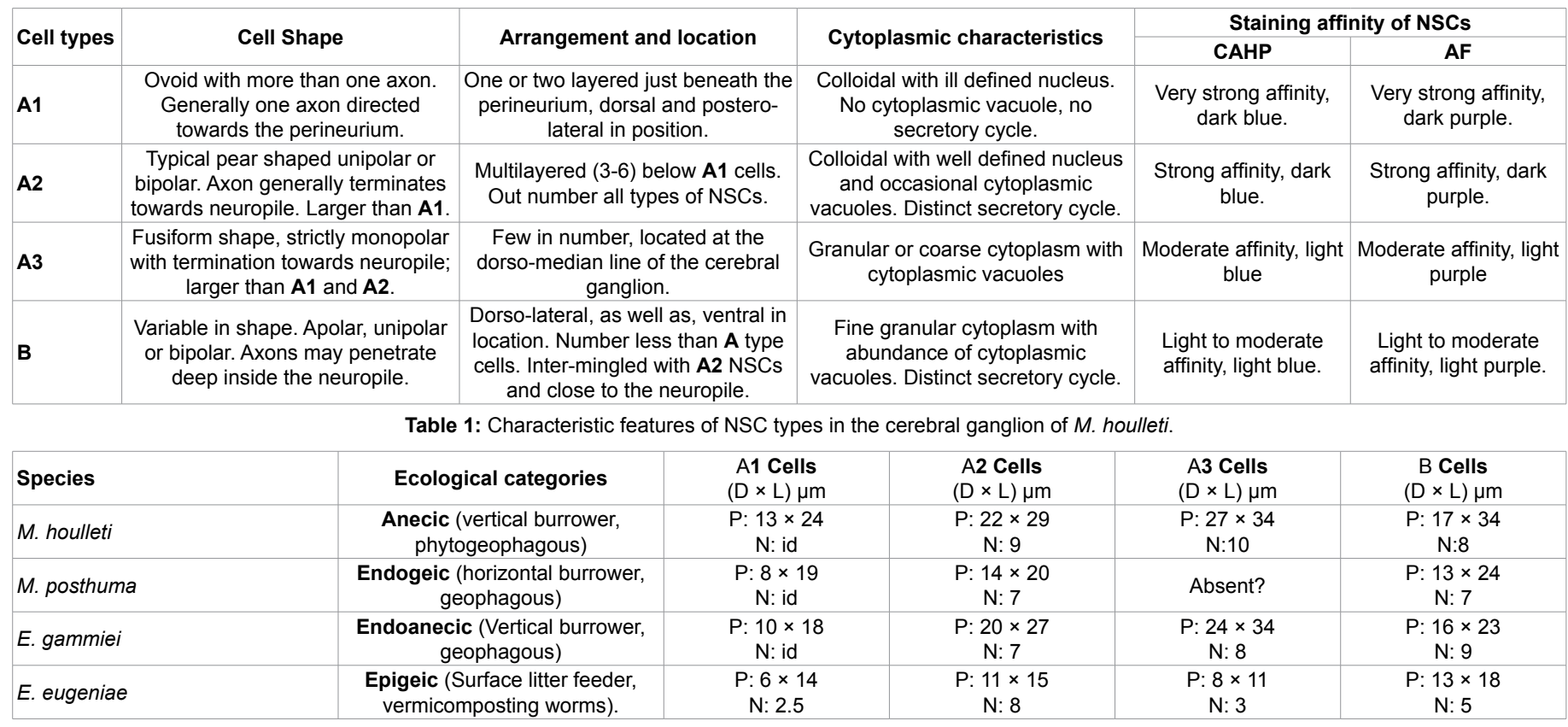

P: Perikaryon: N: Nucleus; id: ill defined; D $\times$ L: Diameter $\times$ Length; N: Number of cells considered.

Table 2: Different earthworm species, their ecological categories and average dimension $(N=20)$ of NSC types

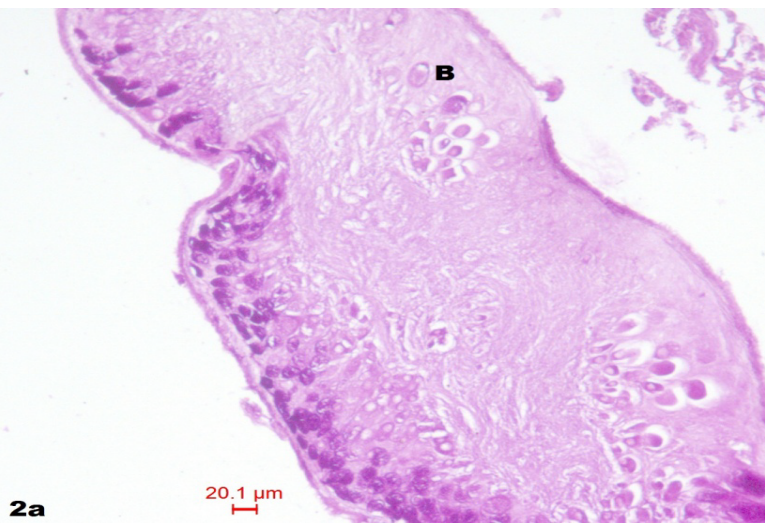

Figure 2a: Section showing rich distribution of AF positive NSCs at the postero- lateral part of cerebral ganglion in M. posthuma. Note distribution of B- NSCs at the ventral part of the ganglion. 100X.

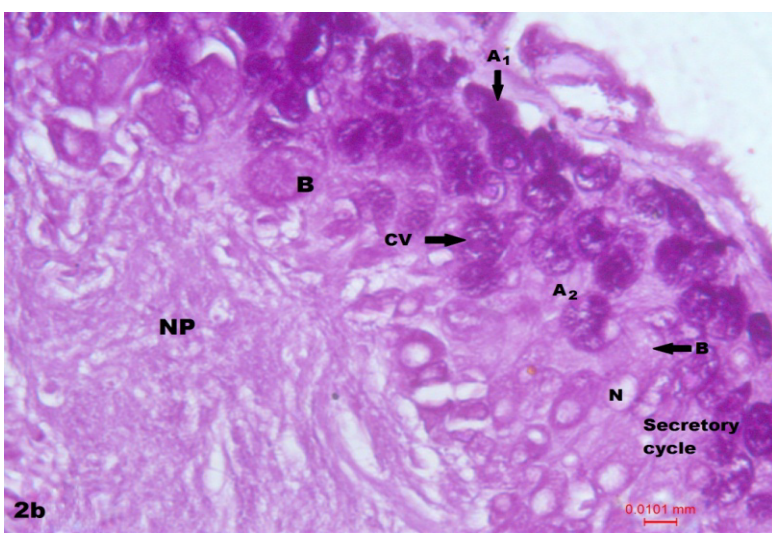

Figure 2b: Frontal section showing secretory cycle in the AF positive NSCs in the 'summer brain' of $M$. posthuma. Note abundance of cytoplasmic vacuoles in both A and B type NSCs. N: Nucleus. 400X

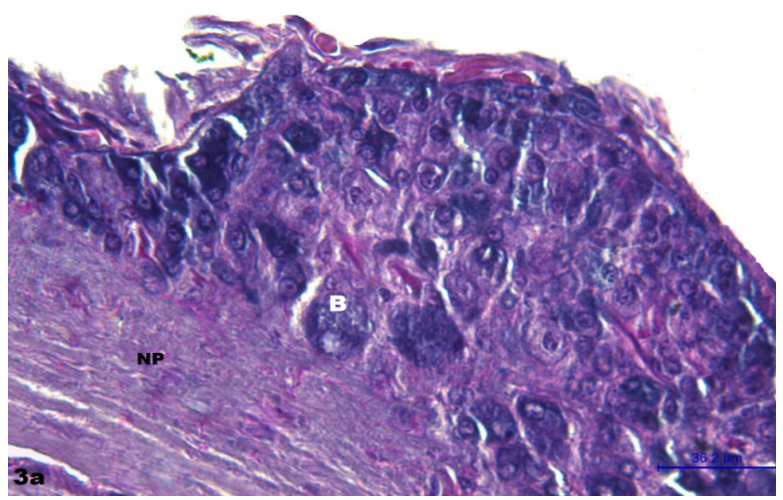

Figure 3a: Frontal section showing compact arrangement of CAHP positive NSCs at postero- dorsal part of ganglion in Eudrilus eugeniae. Note abundance of cytoplasmic vacuoles in B type cells. 100X

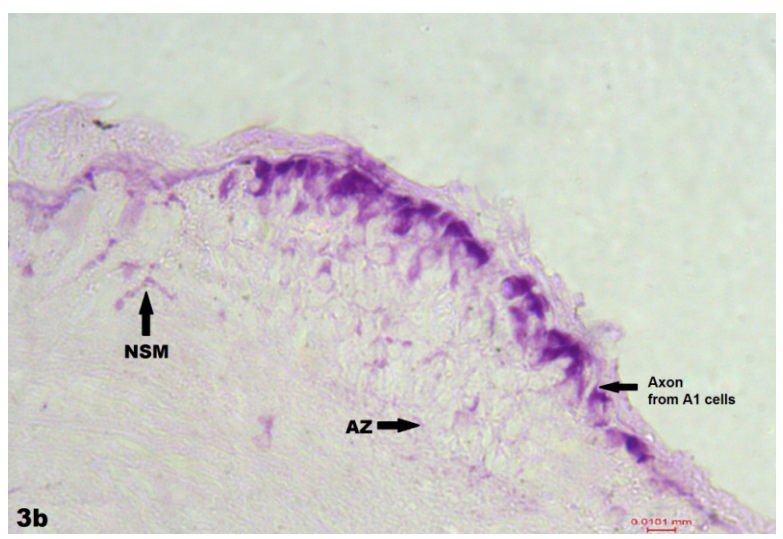

Figure 3b: Frontal section of cerebral ganglion of $E$. eugeniae showing distribution of AF positive A1 NSCs beneath the perineurium. Note 'accumulation zone'(AZ) and blood capillaries charged with NSM. 400X. 


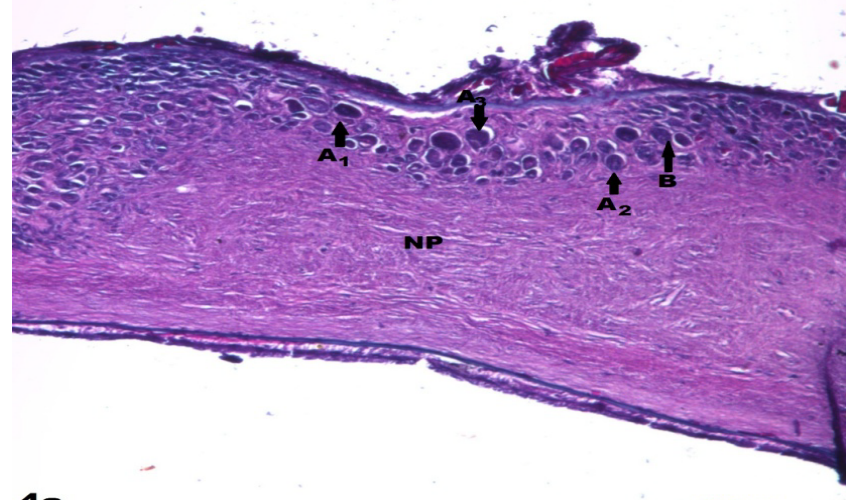

$4 a$

$\stackrel{36.2 \mu \mathrm{m}}{-10}$

Figure 4a: Frontal section of E. gammiei showing distribution of small group of CAHP positive A3 NSCs in the postero-median part. Note intense Gomori positive reaction of the perineurium and neural lamella. 100X

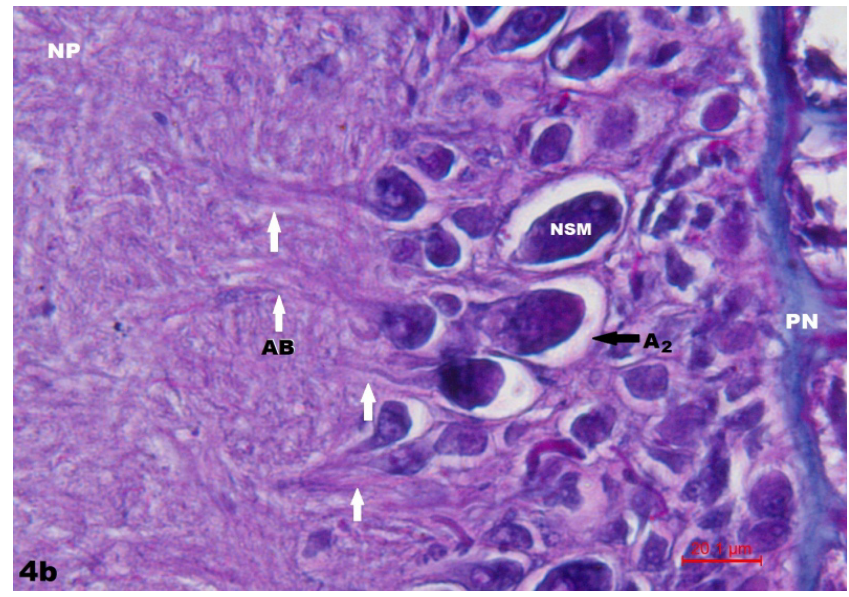

Figure 4b: Frontal section through the postero-dorsal part of the cerebral ganglion of $E$ gammiei showing series of long axon bundles emerging from the CAHP positive A2 cells and penetrating through the neuropile. 400X

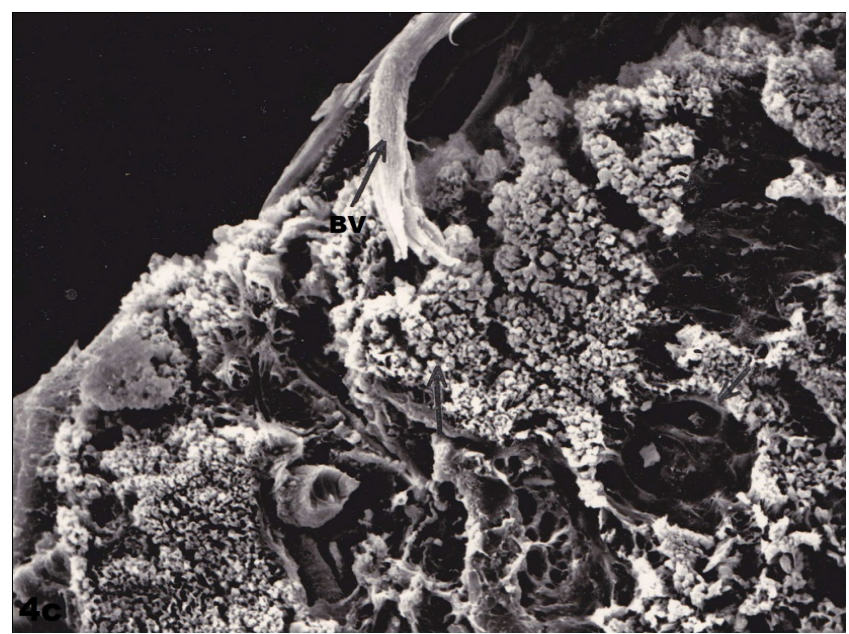

Figure 4c: Surface view of a few large B cells in the cortical cell tier of cerebral ganglion in E. gammiei. SEM, 2000X. [38]

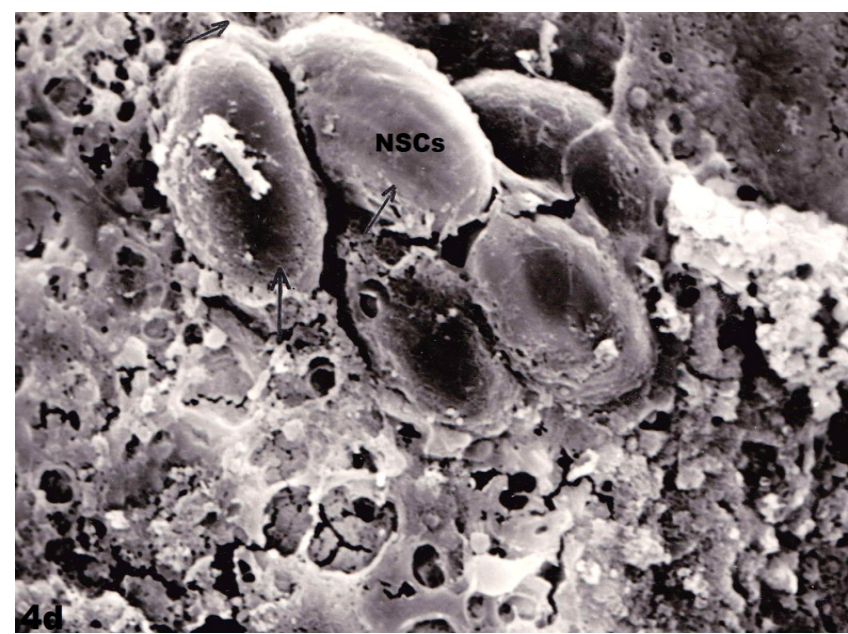

Figure 4d: Magnified sectional view of the cerebral ganglion in E. gammiei showing its blood supply. SEM, 1000X [38]

small and directed towards the perineurium (Figure 3b). Under adult condition A1 cells rarely showed any secretory cycle.

ii) A2-Cells: They were the predominating among A-cell types that formed thick cortical tier beneath the $\mathbf{A} \mathbf{1}$ cells. Generally the axons of A2 cells are directed towards the neuropile (Figures 1d and 4b). Rarely these cells had axonal discharge towards the perineurium. Formation of axon bundles from these cells were not seldom (Figures $4 \mathrm{a}$ and $4 \mathrm{~b}$ ). The A2-cells showed distinct secretory cycle in the summer brain of $M$. posthuma with the onset of breeding season (Figure $2 \mathrm{~b}$ ).

iii) A3-Cells: They were largest among the A type NSCs that stained brightly with CAHP but moderately with AF. A3-cells were few in number and provided with long axons penetrating through the neuropile (Figure $1 b$ ). Generally they formed a very small group at the dorso-median part of the brain.

B-Cells: These were medium and large sized NSCs that stained moderately or lightly with AF stain (Figures 1b, 2b and 3a). B cells were distributed in the inner cortical cell tier, often being intermingled with A2 cells, as well as, around the central fibrous neuropile. They had various shapes (spherical, pyriform, oblong) (Tables 1 and 2). The $\mathbf{B}$ cells, in general, exhibited clear cyto-architecture with centrally placed, abaxonal or axon oriented nuclei, fine to coarse secretory granules scattered throughout the cytoplasm and detectable cytoplasmic vacuoles besides traceable axonal processes. In the brain, $\mathbf{B}$ cells were less in number then A cells. Moreover their numbers were more in the antero-lateral and ventral, than in its postero median part (Figure 2a).

\section{Modes of discharge and storage of NSM}

The NSM elaborated in different NSCs were discharged through the surface of the perikaryon or through the axons into the blood capillaries or tissue spaces. During the activity period (June to October) of the tropical earthworm species, neurosecretory granules (NSM) were found in the axon hillocks and axons of the NSCs irrespective of their types. The discharge of NSM from the $\mathbf{B}$ cells was accomplished either through the perikarya or axonal transport (Figure $4 \mathrm{~b}$ ) or both. There was a rich blood supply to the cerebral ganglion including its outer sheath, perineurium.

A1- cells preferably discharged NSM towards the perineurium through the process of axonal transport (Figure 3b). Axons charged with 
secretory granules were often found to pass through the perineurium to supply the peristomium through the peristomial nerves. However, discharge of secretory materials through axonal transport from A2and A3-cells at the margin of fibrous neuropile was also noticed. This vascular zone because of having appreciable amount of AFpositive NSM has been considered as 'elementary' or 'rudimentary neurohaemal organ'. Although well-defined axon bundles as found in insect brain were not visualized in earthworms, tendency for formation of small tract ('axon bundle') coming out from small group of $\mathbf{A}$ and $\mathbf{B}$ cells were found in their cerebral ganglia (Figure 4b) NSM deposited in the extracellular spaces, around the blood capillaries (Figure $3 \mathrm{~b}$ ), or "accumulation zone" (Figure 1c) or beneath the perineurium (Figure $4 \mathrm{~b})$ found their ways through the posterior or sub neural blood vessels.

\section{Secretory cycle of the NSCs}

The secretory cycle of the NSCs includes the process of elaboration of NSM by the perikaryon, the accumulation of the secretory granules, and finally its discharge and transportation. During late summer and monsoon when earthworms were active, their NSCs irrespective of their types showed distinct secretory cycles with different phases of secretion (Figures 1d, 2b and 3a). In the first phase, the NSCs were nearly devoid of any detectable NSM. However their nuclear membrane showed great affinity to AF and CAHP stains. The nucleus was highly phloxinophilic, the chromatin granules are stained deep blue. This suggests that during this early phase of secretory cycle the nucleus played an important role in the initiation of the neurosecretory activity. The second phase was marked with the appearance of the chromophilic neurosecretory granules which formed aggregates that were spread over a large area of the cell. The third and final phase of neurosecretory cycle differed among $\mathbf{A}$ and $\mathbf{B}$ type cells. In this phase the $\mathbf{A}$ cells were stained deeply purple and blackish violet or blackish blue with AF and CAHP respectively. This homogeneity of the staining was due to the compact arrangement of the neurosecretory granules in the perikaryon (Figures 1c and 1d). The NSM was discharged through the axons either into the tissue spaces or beneath the peripheral vascularised sheath i.e. the perineurium or to the storage zone at the margin of the neuropile (Figures 1c and 1d). In $\mathbf{B}$ cells, during the final phase of secretion, the secretory granules aggregated to form large granules which became most abundant in abaxonal region. The cytoplasm was moderately stained and several cytoplasmic vacuoles appeared inside the perikaryon. The NSM was discharged either through the perikaryon or the axons to the richly vascularized ventral part of the ganglion for their final dispatch (Figures $4 \mathrm{c}$ and $4 \mathrm{~d}$ ).

\section{Discussion}

The cerebral neurosecretory systems in the different ecological categories of earthworm species follow a similar pattern except the differences in size of neurosecretory cell types which may have a bearing with the size of the earthworm species concerned. Classification of NSCs in the cerebral ganglion of earthworms has been made chiefly on the basis of cytomorphological characteristics, their distribution and staining characteristics [12,21-28]. Some of these observations agree with one another but many others differ. Thus it seems difficult to compare our observations with the previous ones concerning the cell types (Table 3). It is even more difficult to establish their homology since the cells of same kind may remain in different phases of secretory activity. Our present cytomorphological studies on the cerebral NSCs in the earthworms viz. M. posthuma, M. houlleti E. eugeniae and E. gammiei reveal four types of NSCs viz. A1-, A2-, A3- and B-cells belonging to two major categories of cells ie. deeply stained A cells and lightly stained $\mathbf{B}$ cells. Available literature indicates that A1-, A2-, A3- cells (together comprise A cells) occupying the postero- dorsal part of the cerebral ganglion of the earthworm species under study comprise the B- DSCs of Chaudhuri et.al. [26] ", dark stained cells” of Dutta and Nanda [27], and ' $\mathbf{a}$ ' or ' $\mathbf{A}$ ' neurosecretory cells of various investigators [21-23,25,26]. According to Al-Yousuf [3] A cells with its different types (A1-A5) are peptide secreting NSCs. Chaudhuri et.al. [11] recorded intense phosphatase activity in the cerebral AF positive deep stained NSCs (corresponding to A cells) of E. gammiei. Earlier, Teichmann et al. [29] have classified A-cells into A1-, A2- and A3-cells in the cerebral ganglia of Lumbricus herculeus and Eisenia fetida on the basis of histochemical characteristics. According to Herlant-Meewis [7] type A1- and A2 cells are possibly the source of somatotrophic and gonadotrophic hormone respectively. Absence of secretory cycle in A1 cells under adult condition indicates that these cells probably remain active during growth phase of the earthworm. In our present studies distinct secretory cycle in the cerebral A2-cells in the summer brain of earthworms reveals their active role in the physiology of reproduction. Chaudhuri et al. [10], Chaudhuri and Chaudhuri [30] reported drastic reduction in the number of deep stained BDSCs (homologous to $\mathbf{A}$ cells) with acute depletion of NSM in cerebral ganglion of E. gammiei following dehydration and hyperthermic conditions. Hypertrophy with increased synthetic activity of $\mathbf{A} \mathbf{1}$ cells in cerebral ganglia of $E$. fetida following light stress was reported by Banovacki and Matavulj [14].

The $\mathbf{B}$ cells in the cerebral ganglia of the species understudy correspond to large and middle sized neurons [20], the 'B' or ' $\mathbf{b}$

\begin{tabular}{|c|c|c|c|c|c|c|c|c|c|c|}
\hline Herlant-Meewis & Hubl & $\begin{array}{l}\text { Michon and } \\
\text { Alaphilippe }\end{array}$ & Aros and Vigh & Takeuchi & Dogra & $\begin{array}{c}\text { Baid and } \\
\text { Gorges }\end{array}$ & $\begin{array}{l}\text { Nanda and } \\
\text { Chaudhuri }\end{array}$ & Al-Yousuf & $\begin{array}{l}\text { Present } \\
\text { study }\end{array}$ & $\begin{array}{l}\text { Physiological } \\
\text { correlates }\end{array}$ \\
\hline A-Cells & $\begin{array}{l}\text { A-cells (in part) } \\
\text { B-cells (in part) }\end{array}$ & A-cells & $\begin{array}{c}\text { A-cells (Small } \\
\text { dark stained cells) }\end{array}$ & A-cells & $\begin{array}{l}\text { A-cells } \\
\text { B-cells }\end{array}$ & A-cells & $\begin{array}{c}\text { Deep stained } \\
\text { cells }\end{array}$ & A 1-A3 & $\begin{array}{c}\text { A1-, A2-and } \\
\text { A3-cells }\end{array}$ & $\begin{array}{c}\text { Growth and } \\
\text { Reproductive } \\
\text { cycle, Thermal } \\
\text { acclimation, } \\
\text { Osmotic balance } \\
\text { (Herlant-Meewis, } \\
\text { Hubl, Chaudhuri } \\
\text { et. al.) }\end{array}$ \\
\hline B-Cells & $\begin{array}{l}\text { A-cells (in part) } \\
\text { B-cells (in part) }\end{array}$ & B-cells & $\begin{array}{l}\text { B-cells (large light } \\
\text { stained cells) }\end{array}$ & $\begin{array}{l}\text { Large and medium } \\
\text { sized neurons }\end{array}$ & & B-cells & $\begin{array}{l}\text { Moderately } \\
\text { stained cells }\end{array}$ & $\begin{array}{l}\text { A4 and A5 } \\
\text { cells }\end{array}$ & B-cells & $\begin{array}{c}\text { Regeneration } \\
\text { (Hubl, Nanda } \\
\text { and Chaudhuri, } \\
\text { Chaudhuri et. al.). } \\
\text { Thermal } \\
\text { acclimation, } \\
\text { osmotic balance, } \\
\text { food intake } \\
\text { (Chaudhuri et al.) }\end{array}$ \\
\hline
\end{tabular}

Table 3: Showing possible equivalence of NSC types in the cerebral ganglia of Oligochaetes*. 
neurosecretory cells of several investigators [21-23,25,26] and moderately stained cells or MSCs of Chaudhuri et al. [26] and Datta and Nanda [27]. Role of moderately stained cells (corresponding to B cells in the present investigation) in regulation of food intake in $M$. peguana and E. gammiei was reported by Chaudhuri et al. [11] and Chaudhuri and Nanda [31]. Distinct secretory cycle with voluminous nuclei and axonal transport of NSM from the moderately stained NSCs (B cells) in the ventral ganglia of $M$. peguana during anterior regeneration was reported by Nanda and Chaudhuri [12]. According to Golding and Whittle [2] A and B type NSCs in the CNS of earthworms have ultrastuctural and histochemical features of peptide secreting and amine secreting cells respectively. By light microscopy, fluorescence and ultramicroscopic studies, both peptide and amine secreting NSCs have been identified in the central nervous system of earthworms, Octolasium complanatum and E. fetida [32,33]. According to Bianchi [33] amine secretion appears to be associated with the perikaryon and is being discharged directly into the blood stream. Thus in our present study prevalence of cytoplasmic vacuoles in the $\mathbf{B}$ cells, indicating direct discharge of NSM from the perikarya [28] may have bearing with amine secreting characteristics. However in E. gammiei and M. houlleti, vacuole rich $\mathbf{B}$ cells with axonal processes terminating either to the neuropile or in the vicinity of blood vessels are not seldom. Thus both perikarial and axonal discharge from different or even the same cell are quite possible. Ultrastuctural studies on the NSCs in the cerebral ganglia of five different species of oligochaeta, Lumbricus terrestris, E. fetida, Octolasium cyaneum, Dendrobaena subbrubicunda and Allolobophora longa by Al-Yousuf [34] indicate the possibility of secretion of hormone from their cell bodies and release of modulators/ transmitters form their axons.

Discrete axonal bundle, as found in insects [15] and chelicerate arthropods [35] although are not available in the cerebral ganglia of M. houlleti, M. posthuma, E. gammiei and E. eugeniae, a tendency for formation of such bundles become evident when A2 and $\mathbf{B}$ cells in their cerebral ganglia are examined. Such conditions are very likely due to the occurrence of 'pool' of these NSCs with functional importance.

Axonal transport with eventual discharge of NSM within the ganglia is evident when their termination to the 'accumulation zone' $[26,36]$ or the neighbourhood of intraganglionic blood capillaries [12,37] are followed upon. In fact, the 'accumulation zone' in all the species under study lies in between the cortical cell layers and the fibrous neuropile and probably combine the function of neuroendocrine control in relation to the storage and release of NSM [2]. Both perikarial and axonal discharge of NSM within the ganglia of the CNS probably necessitate rich vascularization of the neuropile for efficient disposal of hormones in absence of any discrete neurohaemal organ. Our earlier scanning electron microscopic studies on the cerebral ganglia of earthworm, E. gammiei revealed rich distribution of blood capillaries within the neuropile [38]. Thus margin of the vascularized neuropile that receive axon terminals from the NSC groups may serve the purpose of 'plexiform neurohaemal complex' [2], rudimentary [25], incipient [27] or elementary [28] neurohaemal organ. Abundance of NSM beneath the neural lamellae following their release from the superficial cortical cells is an interesting feature of the present investigation. According to Tombes [15] the neural lamella acts as an acellular diffusion medium and a possible reserver for neurosecretory products. In almost all species, neurohaemal areas are not formed within the neural ganglia but on their surface or farther away (outer peripheral sheath above nervous tissues in molluscs, corpus cardiaca in insects and neurohypophysis in vertebrates). The existence of extracerebral "neurohaemal organ" in the earthworm, too, would better fit this general scheme then the intra-cerebral location [39]. Thus in annelids that possess a well differentiated neurohaemal structure situated it the periphery of the brain where coelomic sinus and blood vessels are present, secretion from neurosecretory axon terminals above or below the brain floor diffuse through the neural lamellae and reach the blood stream very easily. The coelomic fluid may be an additional medium for the distribution of neurosecretion [2].

\section{Conclusion}

The studied four tropical earthworm species irrespective of ecological categories show same pattern of cerebral neurosecretory systems except differences in the size of their NSC types. Compared to the anterior and ventral part, the postero- lateral and posteromedian part of the cerebral ganglia display abundance of NSCs. The deeply stained AF- positive A cells forming a thick cortical tier are the predominating NSCs compared to the lightly or moderately stained AF positive B cells located closer to the fibrous neuropile. Distinct secretory cycle in the $\mathbf{A} \mathbf{2}$ cells in the "summer brain" of adult clitellate earthworms indicate their possible role in the reproductive physiology. In absence of well-defined neurohaemal organ in earthworms, there is a phenomenal deposition of NSM in the 'accumulation zone' at the margin of the neuropile and tissue spaces beneath the neural lamella from where secretion readily enters the adjacent capillaries by diffusion [40] to meet physiological need of the earthworms. We propose that in earthworms, the 'accumulation zone' of neurosecretion at the margin of the neuropile and beneath the neural lamella, combine the function of 'elementary' or 'rudimentary' neurohaemal organ.

\section{Acknowledgement}

The authors are grateful to Prof. D. Ghosh, Head of Zoology for encouragement and Prof. B.K. Agarwala, Dept of Zoology, Dr. D. Maiti, State Biotech Hub, Tripura University for allowing microphotographs by Bright- Field Microscope (Lieca), two anonymous referees for their valuable comments. Financial assistance from the Tripura University in the form of research fellowship (Non-NET RET) to the second author is gratefully acknowledged.

\section{References}

1. Scharrer $E$, Scharrer $B$ (1937) Über drüsen-nervenzellen und neuro-sekretorischen organ bei wribellosen teiren und wirbeltieren. Biol Rev 12: 185-216.

2. Golding ML, Whittle AC (1977) Neurosecretion and related phenomenon in Annelids. Int Rev Cytol Suppl 5: 189-302.

3. Al-Yousuf S (1992) Neuropeptides and immunocytochemistry in Annelids. Int Rev Cytol 133: 232-308.

4. Chaudhuri $D$ (1994) On some aspects of neurosecretion in the central nervous system in earthworm Eutyphoeus gammiei (Beddard). Ph.D thesis, University of Calcutta, India.

5. Scharrer E, Scharrer B (1945) Neurosecretion. Physiol Rev 25: 171-181.

6. Takeuchi N (1980) Effects of brain removal on the osmotic and ionic concentration of the coelomic fluid. Comp Biochem Physiol A Comp Physiol 67: 347-352.

7. Herlant-Meewis H (1975) Neurosecretory Phenomena during Reproduction in Oligochaeta. In: Reinboth R (ed.) Intersexuality in the Animal kingdom. Springer-Verlag, Berlin.

8. Molnar L, Pollak E, Skopek Z, Gutt E, Kruk J, et al. (2015) Immune system participates in brain regeneration and restoration of reproduction in the earthworm Dendrobaena veneta. Dev Comp Immunol 52: 269-279.

9. Siekierska $E$ (2002) The stucture of the ovary and oogenesis in gonadotropindeprived earthworm, Dendrobeana veneta (Rosa). Zool Pol 47: 37-48.

10. Chaudhuri D, Chaudhuri PS, Nanda T, Nanda DK (1998) Temperature effect on the cerebral neurosecretory cells of Earthworm, Eutyphoeus gammiei. Indian Biologist 30: 62-65

11. Chaudhuri D, Chaudhuri PS, Nanda DK (1996) The influence of starvation on 
Citation: Chaudhuri PS, Banik D (2015) Cytology and Histology of the Cerebral Neurosecretory Systems in some Tropical Earthworm Species. J Cytol Histol 6: 367j. doi:10.4172/2157-7099.1000367

the brain neurosecretory cells of giant earthworm, Eutyphoeus gammiei. Proc Zool Soc Calcutta 49: 43-50.

12. Nanda DK, Chaudhuri PS (1982) The effect of cephalic transection on the micro morphological changes in the ventral nerve cord neurosecretory system of earthworm Metaphire peguana (Rosa, 1890) during anterior regeneration. Proc Indian Acad Sci (Anim sci) 91: 381-389.

13. Okrzesik J, Kachamakova-Trojanowska N, Jozkowicz A, Morgan AJ, Plytycz B (2013) Reversible inhibition of reproduction during regeneration of cerebral ganglia and coelomocytes in the earthworm Dendrobaena veneta. ISZ 10: 151- 161.

14. Banovacki Z, Matavulj M (2013) Exposure to extremely low frequency $(50 \mathrm{hz})$ electromagnetic field changes the survival rate and morphometric characteristics of neurosecretory neuron of the earthworm Eisenia fetida (oligochaeta) under illumination stress. Arc Biol Sci Belgrade 65: 395-403.

15. Tombes AS (1970) Introduction to Invertebrate Endocrinology. Academic press, New York.

16. Golding DW (1974) A survey of neuroendocrine phenomena in non-arthropod invertebrates. Biol Rev Camb Philos Soc 49: 161-224.

17. Edward CA, Bohlen PJ (1996) Biology and Ecology of Earthworm. London, Chapman and Hall.

18. Nagabhusanam R, Hanumante MM (1974) Hormonal control of blood sugar in the Indian earthworm, Perionyx excavatus. J Sci13: 139-146.

19. Pearse AGE (1960) Histochemistry: Theoretical and Applied. Churchill, London.

20. Cameron ML, Steele JE (1959) Simplified aldehyde-fuchsin staining of neurosecretory cells. Stain Technol 34: 265-266.

21. Hubl H (1956) Ein neuer typ neurosekretorischer zellan in Untersuchlund ganglion der regenwurmer. Naturwiss 43: 284.

22. Aros B, Vigh B (1961) Neurosecretory activity of the central and peripheral nervous system in the earthworm. Acta Biol Hung 12: 169-186.

23. Takeuchi $N$ (1965) Neurosecretory elements in the central nervous system of the earthworm. Sci Rep Tohokn Univ ser iv Biol 31: 105-116.

24. Herlant-Meewis $H$ (1966) [The neurosecretory cells of the nervous chain of Eisenia foetida]. Z Zellforsch Mikrosk Anat 69: 319-325.

25. Baid IC, Gorgees NS (1977) On the neurosecretory system of Dendrobaena atheca Cernosvitov. J Morphol 153: 163-185.

26. Chaudhuri PS, Nanda D. K, Chaudhuri D (1992) Histological studies on the neurosecretory system of the central nervous system in the earthworm, Eutyphoeus gammiei (Beddard). Proc Zool Soc 45: 289-299.
27. Datta M, Nanda DK (1975) Cytomorphological investigation of the supraesophageal ganglion of the opisthopora worm, Pheretima posthuma with special reference to neurosecretion. Zool Pol 25: 13-20.

28. Dogra GS (1968) Studies in-situ on the neurosecretory system of earthworm Pheretima posthuma. J Zool 156: 109-118.

29. Teichmann I, Aros B, Vigh B (1966) Histochemical studies on Gomori-positive substances. 3. Examination of the earthworm's neurosecretory system. (Lumbricus herculeus, Eisenia foetida). Acta Biol Acad Sci Hung 17: 329-357.

30. Chaudhuri D, Chaudhuri PS (1993) Cytomorphic changes in the brain neurosecretory cells of Indian earthworm, Eutyphoeus gammiei exposed to dehydration and subsequent hydration. Proc Zool Soc 46: 105-111.

31. Chaudhuri PS, Nanda DK (1984) The effects of starvation on the ventral nerve cord neurosecretory system of earthworm Metaphere peguana. Acta Biologica Cracoviensia XXVI: 51-55.

32. Bianchi S (1967) The amine secreting neurons in the central nervous system of the earthworm (Octolasium complanam) and their possible neurosecretory role. Gen Comp Endocrinol 9: 343-348.

33. de Vries-Schoumacker $\mathrm{H}$ (1977) Fluorescence and ultrastructural localization of aminergic neurons in the nerve cord of Eisenia foetida (annelida--oligochaeta) Cell Tissue Res 185: 351-360.

34. Al-Yousuf S (1988) Distribution and ultrastructure of neurosecretory cells in the cerebral ganglion of the earthworm. J Morphol 197: 1-20.

35. Chaudhuri PS, Nanda DK, Debnath R (1991) Cytomorphic studies on the neurosecretory cells in the central nervous system of the Indian Horseshoe crab Carcinoscorpius rotundicauda (Latrielle). Functional and Development Morphology 1: 13-16.

36. Chaudhuri PS (1984) Neurosecretion in the ventral nerve cord of earthworm Metaphire peguana (Rosa, 1890). Ph.D thesis, University of Calcutta, India.

37. Oosaki T (1966) Observations on the ultrastucture of nerve cells in the brain of the earthworm, Eisenia foetida with special reference to neurosecretion. Z Zellforsch Microsk Anat 72: 534-542.

38. Chaudhuri D, Chaudhuri PS, Nanda DK (1997) Light and scanning electron microscopic studies on the cerebral neurosecretory system in Indian Octochaetid earthworm, Eutyphoeus gammiei (Beddard). J Adv Zool 18: 102-106.

39. Aros B, Vigh B, Teichmann I (1977) Intra and extra ganglionic nerve endings formed by neurosecretory cells of the cerebral ganglion of the earthworm (Lumbricus terrestris). Cell and Tissue Research 180: 537-553.

40. Haynes LW (1980) Peptide neuroregulators in invertebrates. Prog Neurobio 15: 205-245. 